\title{
Ecumenism and the global anti-apartheid struggle: The World Council of Churches' Special Fund in South Africa and Botswana, 1970-75
}

\author{
Ian Macqueen*
}

\begin{abstract}
This paper argues for the importance of ecumenism as part of the understanding of the global anti-apartheid struggle. Specifically, the paper explores the symbolism and effects of the World Council of Churches' (WCC) decision to fund southern African liberation movements, through the Programme to Combat Racism (PCR) in September 1970. It presents a qualitative analysis of the responses to the grants in South Africa and Botswana, pointing to the mixed results of its funding of the liberation movements and the responses it received in these countries. Reflection on the WCC grants provides insight into a significant element of international pressure on the apartheid regime, in the form of the international ecumenical movement, and an opportunity to contrast South Africa with its northerly neighbour, Botswana. This comparison highlights that the funding to the liberation movements was a political step rather than a purely theological controversy as it has tended to be relegated to through neglect in the mainstream South African historiography.
\end{abstract}

Keywords: Programme to Combat Racism; anti-apartheid movement; ecumenism; anti-racism; solidarity; World Council of Churches.

\section{Opsomming}

Hierdie artikel voer aan dat ekumene as 'n belangrike aspek van die global antiapartheid stryd verstaan moet word. Die artikel fokus op die simboliese waarde en uitwerking van die Wêreldraad van Kerke (WRK) se besluit in September 1970 om Suider-Afrikaanse bevrydingsbewegings deur middel van die Program vir die

* Ian Macqueen is a lecturer in the Department of Historical and Heritage Studies, University of Pretoria, and a Research Associate of the Society, Work and Development Institute (SWOP), University of the Witwatersrand. This research was made possible by funding through an Innovation Postdoctoral Grant of the National Research Foundation. My thanks to all the interviewees for sharing their perspectives, and especially to Howard and Dave Trumbull for granting me access to their private documents. Since this research was conducted, Howard Trumbull sadly passed away.

How to cite this article: Ian Macqueen, "Ecumenism and the global anti-apartheid struggle: The World Council of Churches' Special Fund in South Africa and Botswana, 1970-75", Historia, 62, 2, November 2017, pp 87-111.

http://dx.doi.org/10.17159/2309-8392/2017/v62n2a5

Copyright: (CThe Author(s). Published under a Creative Commons Attribution Licence. 
Bekamping van Rassisme te befonds. 'n Kwalitatiewe analise van die reaksies op die toelaes in Suid-Afrika en in Botswana word verskaf. Dit dui op die gemengde gevolge van die befondsing vir die bevrydingsbewegings en die reaksies wat dit in hierdie lande uitgelok het. Deur die WRK toelaes te bestudeer, word nuwe insig verkry oor hierdie belangrike aspek van internasionale druk op die apartheid regime. Dit verskaf ook 'n geleentheid om Suid-Afrika met haar noordelike buurland, Botswana, te vergelyk. Hierdie vergelyking benadruk die feit dat die befondsing aan die bevrydingsbewegings 'n politieke stap was - nie 'n rein teologiese twispunt, soos wat dit in die hoofstroom Suider-Afrikaanse historiografie beskou, en daarom verwaardeloos word, nie.

Sleutelwoorde: Program vir die Bekamping van Rassisme; anti-apartheidbeweging; ekumenisme; anti-rassisme; solidariteit; Wêreldraad van Kerke.

\section{Introduction}

Research on the international anti-apartheid movement has yielded an impressive body of research but has neglected the role of ecumenical organisations. Chief among these organisations was the World Council of Churches (WCC), founded in Amsterdam in 1948, which represented most Orthodox and Protestant churches of the world. ${ }^{1}$ The role of religion in the anti-apartheid struggle has been addressed by Rob Skinner, who has shown the importance of the role of Christian priests such as Trevor Huddleston, Michael Scott and John Collins in laying what Skinner terms "the moral foundations" of the anti-apartheid movement. ${ }^{2}$ In the 1970s in particular, what Christabel Gurney characterises as the Anti-Apartheid Movement's "difficult decade", the WCC acted as a powerful and radical source of pressure on apartheid South Africa and Rhodesia, and was an important source of revenue for Botswana's support of refugees. ${ }^{3}$ Yet the organisation has received scant attention, for example in in Håkan Thörn's important study of the Anti-Apartheid Movement the WCC is only mentioned four times, and then only in passing. ${ }^{4}$

1. H. Thörn, Anti-Apartheid and the Emergence of a Global Civil Society (Palgrave Macmillan, Houndsmills, 2006); R. Skinner, The Foundations of Anti-Apartheid: Liberal Humanitarians and Transnational Activists in Britain and the United States, c.1919-64 (Palgrave Macmillan, Houndmills, 2010); E. Williams, The Politics of Race in Britain and South Africa: Black British Solidarity and the Anti-Apartheid Struggle (I.B. Tauris, London, 2012).

2. R. Skinner, "The Moral Foundations of British Anti-Apartheid Activism, 1946-1960," Journal of Southern African Studies, 35, 2 (2009), pp 399-416.

3. C. Gurney, "The 1970s: The Anti-Apartheid Movement's Difficult Decade", Journal of Southern African Studies, 35, 2 (2009), pp 471-487.

4. Thörn, Anti-Apartheid and the Emergence of a Global Civil Society. 
This article, through a combination of oral interviews ${ }^{5}$ and close reading of the documentary record, demonstrates the significance of the WCC in the anti-apartheid struggle. It does this by focusing on the symbolism and effects of the most controversial decision that the world organisation made, which was to fund the liberation movements of southern Africa in September 1970 under the aegis of its Programme to Combat Racism (PCR). The decision of the WCC was the culmination of a series of consultations which convinced the WCC that racism posed a grave global threat, and that apartheid, as its most blatant institutional expression, had to be confronted. Funding liberation movements committed to change through any means necessary, including violence, at its root evoked the concerns of "just war" theory. An ancient debate, it addressed the question of whether Christians could ever be justified to support the use of violence to achieve an end. ${ }^{6}$ This article is not in the first place concerned with the ethics of the decision; rather, it identifies this as a moment that heightened the importance of the ecumenical movement as a source of pressure on the apartheid regime and an unequivocal expression of support for the aspirations of the black oppressed in South Africa, Rhodesia and South West Africa. The article points to the mixed results of the WCC funding of the liberation movements and the differing responses it received in South Africa and Botswana. As a site of refugees who were beneficiaries of the WCC money, Botswana serves as a point of contrast to the apartheid regime, where the polarisation caused by the WCC decision was most apparent.

Ecumenism refers to the drive for a practical expression of unity of faith amongst Christian churches, but its broader interpretation entails a responsibility to

5. The article draws on three oral interviews conducted by the author. The first was with Bobby Marie in Johannesburg, 15 February 2013. Marie grew up in South Africa classified as an Indian under apartheid and was involved from a young age in the Presbyterian Indian Mission in Meerbank. He provided important perspectives on how young people classified as "non-white" under apartheid interpreted the WCC grants. The second interview was with Howard (father) and Dave (son) Trumbull, via Skype on 22 May 2013. The Trumbulls were a missionary family employed in Botswana, and were involved in distributing the WCC funds this article explores. The third interview was held with Bernard Spong, a former communications director of the South African Council of Churches (SACC), in Johannesburg on 19 June 2013. Spong has also researched and published on the history of the SACC. See for example B. Spong and C. Mayson, Come Celebrate! Twenty-Five Years of Work and Witness of the South African Council of Churches (South African Council of Churches, Johannesburg, 1993). Lastly, the article also draws on email correspondence with Professor James Amanze, Department of Theology and Religious Studies at the University of Botswana, one of the few scholars who have conducted research on the Botswana Christian Council.

6. Saint Augustine and Saint Thomas Aquinas both devoted attention to conditions under which Christians were allowed to take up arms, to commit violence for a particular cause. Some traditions of Christianity have never accepted the use of violence and reject the notion of a "just war". See Internet Encyclopaedia of Philosophy, "Just War Theory", http://www.iep.utm.edu/justwar/ Accessed 3 April 2017. 
the entire world, which significantly included politics. In its emphasis on the unitary nature of faith, humankind and indeed the entire world, ecumenism was ideologically opposite to apartheid. The fact that both were informed powerfully by theology and readings of the Bible made their conflicting imaginaries all the more apparent; they in effect both spoke the same language of theology, although arriving at vastly different conclusions. ${ }^{7}$

The ecumenical movement included international bodies such as the All Africa Conference of Churches (AACC), the World Alliance of Reformed Churches (WARC), the Ecumenical Association of Third World Theologians (EATWOT), and most prominently, the World Council of Churches (WCC). In her recent doctoral study, Thembeka Mufamadi observes that "in the mainstream historiography of South Africa there is a surprising lack of interest in the involvement of the WCC in the anti-apartheid struggle". ${ }^{8}$ Instead, the detailed history of the WCC involvement in southern Africa has been limited to accounts of the history of Christianity in the region. ${ }^{9}$ While the grants, which were international in scope, have been addressed in a number of studies, as discussed below, they remain under-researched in terms of their symbolism and effects for southern Africa as a region. The grants are also mentioned in general histories of the period, as Mufamadi shows, including the documentary history of Thomas Karis and Gail Gerhart, a chapter by Sifiso Ndlovu, and a study of black resistance by Jackie Grobler. ${ }^{10}$ The landmark South African Democracy Education Trust

7. For more, see my article, I. Macqueen, "Students, Apartheid and the Ecumenical Movement in South Africa, 1960-1975", Journal of Southern African Studies, 39, 2 (2013), pp 447-463.

8. T. Mufamadi, "The World Council of Churches and its Programme to Combat Racism: The Evolution and Development of their Fight against Apartheid, 1969-1994", PhD thesis, University of South Africa, 2011, p 16.

9. See for example, J. De Gruchy, The Church Struggle in South Africa, 2nd ed. (Eerdmans and David Philip, Grand Rapids and Cape Town, 1986); G. Duncan and A. Egan, "The Ecumenical Struggle in South Africa: The Role of Ecumenical Movements and Organisations in Liberation Movements to 1965", Ecclesiastical Law Journal, 17, 3 (2015), pp 269-282; G. Setiloane, "The Ecumenical Movement in Africa: From Mission Church to Moratorium', in C. Villa-Vicencio and J.W. De Gruchy (eds), Resistance and Hope: South African Essays in Honour of Beyers Naude (Eerdmans, Grand Rapids, 1985); and E. Strassberger, "Ecumenism in South Africa 1936-1960 with Special Reference to the Mission of the Church", DTh thesis, Stellenbosch University, 1971.

10. Mufamadi, "World Council of Churches and its Programme to Combat Racism", p 9; T.G. Karis and G.M. Gerhart (eds), From Protest to Challenge: A Documentary History of African Politics in South Africa, 1882-1990, Volume 5, Nadir and Resurgence, 1964-1979 (Unisa Press, Pretoria, 1997), pp 81-83; S.M. Ndlovu, "The ANC in Exile", in South African Democracy Education Trust, The Road to Democracy in South Africa, Volume 1 (1960-1970) (Zebra Press, Cape Town, 2004), pp 567-570; J.A. Grobler, Decisive Clash: A Short History of Black Protest Politics in South Africa, 1875-1976 (Acacia, Pretoria, 1988), p 147. 
series, The Road to Democracy in South Africa, contributes two chapters to the contributions of faith-based organisations to the struggle against apartheid, but only in its volume on the 1980s, and therefore does not deal with the 1970s, the period in which the WCC grants were initially made. ${ }^{11}$

The first evaluation of the grants was conducted in 1974 at the behest of the WCC by Elisabeth Adler, a former associate general secretary of the World Student Christian Federation (WSCF) who lived in the German Democratic Republic and grew up in Nazi Germany. Adler's subsequent report labelled the PCR "a small beginning", recognising the enormity of the challenge of racism in the twentieth century and the comparatively small, symbolic gesture of the WCC to fund organisations that it viewed to be combating racism around the world. Adler saw South Africa as but one instance of a global challenge and her analysis linked apartheid to the Holocaust, the American civil rights struggle and Africa's wars of liberation. ${ }^{12}$ Darril Hudson, an American political scientist, next analysed the PCR and WCC as part of what Lester Salamon, a pioneer of the study of non-profit organisations, later characterised as the "associational revolution" of the twentieth century, ${ }^{13}$ when non-governmental organisations (NGOs) increasingly sought to exercise influence to effect policy changes in global politics. ${ }^{14}$ Another study of the WCC by the Dutch reporter J.A. Emerson Vermaat provides a broad survey of its activities in the middle of the Cold War, and devotes one chapter to the impact of the PCR on southern Africa. However, this work focuses on the struggle in Zimbabwe in the late 1970s, showing particularly the difficult position the WCC found itself in because of its unequivocal support for Robert Mugabe. ${ }^{15}$ A lay preacher and organiser of religious broadcasting of the World Service of the British Broadcasting Corporation (BBC),Pauline Webb, edited an important book that the WCC issued in 1994, with contributions by leading participants in its struggle with apartheid, such as the PCR's first director, Baldwin Sjollema; Black Consciousness activist and later PCR director, Barney Pityana; Elisabeth Adler, and theologian Charles Villa-Vicencio. This publication surveyed the PCR's contribution to the attainment of

11. S. Zondi, "Of Faith and Action: Aspects of the Role of Faith Institutions in the Struggle against Apartheid", South African Democracy Education Trust, The Road to Democracy in South Africa, Volume 4, Part 2, 1980-1990 (Unisa Press, Pretoria, 2010), pp 14391481; and C. Mayson, "The Story of the Christian Institute", in South African Democracy Education Trust, The Road to Democracy in South Africa, Volume 4, pp 1483-1521.

12. E. Adler, A Small Beginning: An Assessment of the First Five Years of the Programme to Combat Racism (World Council of Churches, Geneva ,1974).

13. L. Salamon, "The Rise of the Non-profit Sector," Foreign Affairs (1994), pp 109-122.

14. D. Hudson, The World Council of Churches in International Affairs (The Faith Press, London, 1977).

15. J.A. Emerson Vermaat, The World Council of Churches and Politics, 1975-1986 (Freedom House, New York, 1989). 
democracy in South Africa, whilst recognising the continued challenges that the new democracy faced. 16

More recently, Claude E. Welch, Jr, the director of the Human Rights Center, State University of New York, argued that with the Programme to Combat Racism, the WCC engaged in a form of symbolic politics, by which the symbolic impact of an action was intended to expand the interests of the moral cause involved, a tactic that became common for NGOs which were faced by powerful governments. As Welch recognises, "the PCR represented one of the most dramatic gestures for change the WCC had ever made". ${ }^{17}$ While Welch's article does focus on southern Africa, it gives quite limited detail on the initial years of the grants, rather surveying their broader impact from their implementation in 1970 to the end of apartheid in 1994. The most recent researcher to address the role of the WCC is Thembeka Mufamadi, who draws on archival research conducted in South Africa and Geneva, the home of the WCC archives, to assess the contribution of the WCC to bring an end to apartheid. She posits that the WCC "acted as a political interest group, a transnational advocacy network, and a significant religious sector within global civil society, which contributed to the transformation of South African society".18

\section{The Road to the Special Fund}

Growing out of the international missionary councils and formed in 1948 in the context of the ruins of a post-WW2 world, the WCC was strongly aware of the threat of race thinking, most extremely manifested in colonial genocides such as the systematic slaughter of the Nama and Herero in German South West Africa between 1904 and 1907 by the German colonists, and the Holocaust. One of the WCC founders, the Scot Joseph Oldham, had written a monograph Christianity and the Race Problem (1924) attacking scientific racism. ${ }^{19}$ Although there was thus a history of the WCC engagement with race as a problem of the twentieth century, the most definite moves towards combating racism, and particularly white racism, crystallised at the Fourth Assembly of the WCC at Uppsala, Sweden, from 4 to 20 July 1968. Sjollema, a sociologist from the Netherlands who grew up under Nazi occupation was closely involved in the process and later recalled that "when the churches met at the assembly of the WCC in Uppsala in 1968, they were confronted with a world in turmoil [and] one of the major issues

16. P. Webb (ed.), A Long Struggle: The Involvement of the World Council of Churches in South Africa (WCC Publications, Geneva, 1994).

17. C.E. Welch, "Mobilizing Morality: The World Council of Churches and its Program to Combat Racism, 1969-1994", Human Rights Quarterly, 23, 4 (2001), p 865. See also Adler, A Small Beginning.

18. Mufamadi, "World Council of Churches and its Programme to Combat Racism", p 261.

19. Oldham, had been a missionary to India. He was prominent in the first international missionary councils, that were integral to the genesis of the ecumenical movement. See J. Oldham, Christianity and the Race Problem (George H. Doran, New York, 1924). 
was racism."20 Martin Luther King Jr. was scheduled to give the sermon at Uppsala Cathedral and his assassination in Memphis, Tennessee on 4 April 1968 underlined the reality and international scope of racism. The challenge of King's assassination was further heightened by a stirring presentation by African American intellectual, James Baldwin, in which he averred: “ ... long ago, for a complex of reasons, but among them power, the Christian personality split into two - into dark and light, and is now bewildered and at war with itself". He called on the assembly to "repent" and be "born again". ${ }^{21}$ Delegates to the consultation recognised the need for urgent action, and responded by calling Christians around the world "to seek to overcome racism wherever it appears". ${ }^{22}$ After the Uppsala assembly, the Central Committee mandated its permanent staff "to give serious consideration to the ways in which a programme for the Elimination of Racism might be implemented". ${ }^{23}$

The first step the WCC staff took was to hold an international Consultation on Racism in London from 19 to 24 May 1969, to determine a course of education and action to combat racism, with a specific view to "make a new exploration of the nature, causes and consequences of racism in the light of contemporary conflict situations, the means being used it combat it, and the possibilities of new Christian witness in this area". ${ }^{24}$ The consultation, held in London, comprised of 40 Christians, drawn from the laity and clergy from around the world and 25 consultants. Significantly, the consultation hosted powerful black speakers who minced no words about the inequities faced by those subjugated in the Third World particularly. Joe Matthews, the son of anti-apartheid activist Professor Z.K. Matthews, addressed the consultation as a representative of the African National Congress (ANC). ${ }^{25}$ Putting across the case for the armed struggle, he drew direct parallels with Europe's own recent struggle with Nazism, which was defeated through arms. As he pointed out to the conference:

You fellows established resistance movements against Nazism. You bombed people; you sabotaged trains; you killed people. And now you want to prevent us from fighting in the same way against apartheid. You Europeans are inconsistent. When it suits you, you are the most violent people and then, when we have to fight for our liberation, suddenly you say that this is philosophically unacceptable for Christians. ${ }^{26}$

20. B. Sjollema, Never Bow to Racism: A Personal Account of the Ecumenical Struggle (WCC publications, Geneva, 2015), p xi.

21. Cited in B. Sjollema, "The Initial Challenge", in Webb (ed.), A Long Struggle, p 9.

22. Cited in World Council of Churches, Minutes and Reports, 23rd Meeting, University of Kent, Canterbury, 12-22 August 1969 (WCC publications, Geneva, 1969), p 270.

23. Cited in World Council of Churches, Minutes and Reports, August 1969, p 270.

24. World Council of Churches, Minutes and Reports, August 1969, p 270.

25. Mufamdai, "World Council of Churches and its Programme to Combat Racism", p 10.

26. "Joe Gaobakwe Matthews", in South African Democracy Education Trust, The Road to Democracy: South Africans Telling their Stories, Volume 1 (Molautse Heritage Trust), at 
Herbert Chikomo of the Rhodesian Christian Council also spoke at the consultation where he drew the delegates' attention to the history of racism in Rhodesia and its legal enshrinement in the Land Apportionment Act. ${ }^{27}$ In its conclusion the consultation called on the WCC and its member churches to create an ecumenical programme to combat racism, as well as to "offer a convincing moral lead in the face of this great and growing crisis of our times". ${ }^{28}$ As a result of the deliberations, at its next meeting at the University of Kent, Canterbury in August 1969 the WCC Central Committee set up the Programme to Combat Racism (PCR). The specific emphases of the PCR were fivefold: a focus on white racism as "by far the most dangerous form of present racial conflicts"; challenging institutional racism manifested in "economic and political power structures"; a redistribution of "social, economic, political and cultural power from the powerful to the powerless"; multiple strategies to achieve these aims; and the recognition of the Church's complicity "in benefiting from and furthering white racism"(emphasis original). ${ }^{29}$

The Central Committee appointed a permanent staff coordinating group to run the programme, and selected Sjollema as the first executive secretary, effective from February $1970 .{ }^{30}$ Sjollema later reflected that his "involvement in the work of the WCC" was a "direct sequence of my experience in the Second World War". ${ }^{31}$ The Central Committee also appointed Nawaz Dawood, a lawyer from then Ceylon, who joined on 1 August 1970, and Rev. Charles Spivey, an African American who was a former executive director of the Department of Social Justice, who took the post as secretary in December 1970.32 At the Canterbury Consultation, the Central Committee also elected to set up a Special Fund to Combat Racism, providing the fund with a total amount of $\$ 200,000$ drawn from the WCC's reserves. ${ }^{33}$ The Central Committee made an appeal to its member churches to donate a further $\$ 300,000$ to the Special Fund, a

http://www.sadet.co.za/docs/RTD/stories/Stories\%20-\%20Joe\%20Matthews.pdf Accessed 31 July 2017.

27. H. Chikomo, "The Struggle of the Church with a Racial Government Policy - Rhodesia", WCC Consultation on Racism, London, 19 to 24 May 1969. Available online at http://www.aluka.org/action/showMetadata?doi=10.5555/AL.SFF.DOCUMENT.ydlw cc0149 Accessed 4 June 2013. At the same time, Chikomo seemed to have his own ambitions for a political career. In London he mooted the possibility of forming a moderate African political party, which he contended would be able to incorporate the liberation movements ZANU and ZAPU.

28. World Council of Churches, Minutes and Reports, August 1969, p 271.

29. World Council of Churches Central Committee, Minutes and Reports of 24th Meeting, Addis Ababa, Ethiopia, 10 to 21 January 1971 (WCC publications, Geneva, 1971), p 238.

30. Joe Matthews recalled being offered the position of director first but maintains he turned it down, after which it was offered to Sjollema, see "Joe Gaobakwe Matthews".

31. Sjollema, Never Bow to Racism, p xii.

32. WCC, Central Committee, Minutes and Reports of 24th Meeting, pp 238-239.

33. WCC, Central Committee, Minutes and Reports of 24th Meeting, $\mathrm{p} 241$. 
call which was met with a limited response. In 1970 the staff coordinating group conducted its initial research and drew up profiles of the humanitarian programmes of FRELIMO (Mozambique), PAIGC (Guinea-Bissau) and the ANC (South Africa), which were each deemed to be fighting a form of racism in their particular context and therefore qualified to receive grants from the Special Fund. ${ }^{34}$ The favouring of these organisations may also have been due to the influence of exiled members such as Joe Matthews of the ANC who presented their organisations in a favourable light.

In September 1970 at its meeting in Arnholdshain, Germany, the Central Committee announced the first of the grants, a division of the $\$ 200,000$ that would be made to 19 organisations, which included the liberation movements of southern Africa, through the Special Fund. ${ }^{35}$ The amounts given to the individual liberation movements were relatively small ( $\$ 10,000$ was allocated to the African National Congress), and were expressly for humanitarian projects and not for military purposes. ${ }^{36}$ Nonetheless, the decision by the WCC was a watershed moment that divided the church worldwide, because it appeared to give tacit support to the use of violence by oppressed peoples to achieve social justice, an ethical question that was deeply divisive for the Christian churches. Within the WCC itself at the meeting of its Central Committee in Addis Ababa, Ethiopia, from 10 to 21 January 1971, there was considerable debate on the question of whether violence could ever be condoned by Christians to achieve social change, a question on which the assembly was unable to reach a consensus. The final resolution on the Programme to Combat Racism reflected this division because it refused to "identify itself completely with any political movement". It noted that violence was "in many cases inherent in the maintenance of the status quo" and refused to "pass judgement on those victims of racism who are driven to violence" to "open the way for a new and more just social order". ${ }^{37}$ The decision to embark on the funding of the liberation movements was a deeply divisive one for the WCC itself, but the world body was sufficiently convinced of the necessity to give symbolic support to the cause of fighting racism in the world. It was the symbolism of this action more than anything else that led to shockwaves through South Africa.

34. WCC, Central Committee, Minutes and Reports of 24th Meeting, p 242.

35. WCC, Central Committee, Minutes and Reports of 24th Meeting, p 241.

36. The turn to armed struggle by the ANC has itself been the subject of renewed debate between Scott Couper and Raymond Suttner. See S. Couper, "Emasculating Agency: An Unambiguous Assessment of Albert Luthuli's Stance on Violence", South African Historical Journal, 64, 3 (2012), pp 564-586; and R. Suttner, "'The Road to Freedom Is via the Cross': 'Just Means' in Chief Albert Luthuli's Life", South African Historical Journal, 62, 4 (2010), pp 693-715.

37. WCC, Central Committee, Minutes and Reports of 24th Meeting, p 55. 


\section{The impact of the Special Fund on South Africa}

In the years immediately following the Second World War, South Africa fell rapidly from grace; its position of international prestige as one of the victorious Allies faded. Whereas just after the war the prime minister, J.C Smuts, had comfortably penned the words of the United Nations Preamble, the implementation of apartheid by the Afrikaner Nationalist Party in 1948 led the country to be viewed as an international pariah, backward in its thinking and opposed to the path of progress. As Saul Dubow writes, part of the international moral repugnance against apartheid South Africa, which was implemented with the victory of the National Party in the same year as the WCC's formation in 1948, was that apartheid amplified race at the very moment that world opinion was moving in a concerted way against racism. ${ }^{38}$ The Sharpeville Massacre of 21 March 1960 exposed the divergence between the white minority regime and world thinking even more tragically. The churches in South Africa affiliated to the CCSA individually, and to the WCC separately. This allowed the WCC to bypass the CCSA and call for a direct consultation with the churches in South Africa as a response to Sharpeville. The subsequent Cottesloe Consultation became significant for church history in South Africa as a touchstone for progressive values. It saw the moral and theological rejection of apartheid by all delegates, including participants from the Dutch Reformed Church (DRC). ${ }^{39}$ The South African prime minister at the time, Hendrik Verwoerd immediately intervened, however, and under pressure from him and the government, by 1961 the DRC churches left the WCC. Although ineffective in creating immediate change, Cottesloe had an enduring impact through its inspiration in the minds of young and older South Africans of an alternative, open society. This led in part to Beyers Naudé's launching of the Christian Institute of Southern Africa in 1963 , an ecumenical organisation that was to play a crucial role in ecumenism in South Africa until the state stepped in to shut it down in 1977.40

In 1967 the CCSA appointed South African Archbishop Bill Burnett as its general secretary, a significant move for an organisation that until that point had been led by foreign-born clergy. Burnett, in contrast was later described as an "indigenous bilingual bishop". 41 The following year in May 1968, the CCSA changed its name to the South African Council of Churches (SACC) and in the same year it released a public statement, a "Message to the People of South Africa", that rejected apartheid as a "false

38. S. Dubow, Scientific Racism in Modern South Africa (Cambridge University Press, Cambridge, 1995), p 19.

39. Macqueen, "Students, Apartheid and the Ecumenical Movement", p 450.

40. C. Ryan, Beyers Naudé: Pilgrimage of Faith (David Philip, Cape Town and Johannesburg, 1990).

41. J. Robertson, "Obituary: The most Rev Bill Burnett", The Independent, online at http://www.independent.co.uk/news/people/obituary-the-most-rev-bill-burnett1447654.html Accessed 2 April 2017. 
faith" that was "inevitably ... in conflict with the Gospel of Jesus Christ". 42 This commitment of the SACC was to be sorely tested over the subsequent years, particularly by the symbolic politics of the WCC's decision to create a special fund to disseminate funds to organisations internationally that the WCC considered to be fighting racism.

In reality, the WCC grants also created particular difficulties for those working for the end of apartheid in South Africa, under the umbrella of Christian organisations, because it threatened to provide the government with an easy opportunity to censure them. The day after the WCC released its statement, on 8 September, the SACC met in Johannesburg and issued its own statement dissociating itself from the "implied support of violence" and also stressing that the SACC was not represented when the WCC took the decision. Beyers Naudé, the founder of the Christian Institute and by then already a prodigal of Afrikanerdom, also issued a statement to the effect that the Christian Institute rejected the use of violence as a means of bringing about change. W.B. de Villiers, the editor of the monthly ecumenical periodical Pro Veritate, observed, however, the silence of black Christians in response to the grants. ${ }^{43}$ Black students in the periodical SASO Newsletter also remarked that the official church statements made them "feel black opinion is regarded as extremely unimportant" and that the white church leadership "who speak on behalf of an overwhelmingly black membership" needed to "find out what the people really think". ${ }^{4}$

The Bishop of Zululand, Alphaeus Zulu, who was a president of the World Council of Churches at the time, and the first black bishop of the Anglican Church of the Province of South Africa (CPSA) ever to be elected, was the only Church leader to initially give a public comment on the decision by the WCC to provide the liberation movements with money. In fact Zulu condemned the decision as rash, noting how the South African churches had not been properly consulted in the lead up to the decision. ${ }^{45}$ The South African state was in fact guilty of preventing such consultation, by refusing to issue Zulu with a visa to attend the crucial Uppsala Assembly in July 1968. But Zulu's stance reflected a wider response of Christians and also showed that not all black South Africans supported the WCC for its decision to set up the special fund, although that number must have been small. Like his erstwhile contemporary, Chief Albert Luthuli, Bishop Zulu was committed to change through peaceful means. He was also opposed to the divestment campaign against South Africa, which called for international companies to leave the country in protest against apartheid, for fear that

42. South African History Online, "A Message to the People of South Africa: Authorised Summary, 1968", online at http://www.sahistory.org.za/archive/a-message-to-thepeople-of-south-africa-authorised-summary,-1968 Accessed 2 April 2017.

43. W.B. de Villiers, Pro Veritate, 9, 6 (October 1970, p 2.

44. SASO Newsletter, September 1970, p 5.

45. P. Walshe, Church versus State in South Africa: The Case of the Christian Institute (C. Hurst \& Co., London, 1983), p 115. 
it might impact negatively on the poor, who were almost exclusively black. Although Zulu was committed to the principle of non-violence, he was fully aware of the multitude of reasons that could be used to support such a cause. As he reflected in his T.B. Davie memorial lecture to the University of Cape Town in 1972, the continued discrimination of black people in South Africa, and the failure of the mass protests of the 1950s, made a black man look "simple and naïve if he continues to believe and talk of non-violence ever becoming effective". ${ }^{46}$ Zulu never accepted a violent alternative opposition to apartheid, despite the tremendous moral and emotional pressure there must have been to do so. He was prepared to go further, and advocated that the South African Churches should resign from the WCC en bloc. ${ }^{47}$ By 1974, he was prepared to resign from his post as president of the WCC, even if the South African churches did not follow him. ${ }^{48}$ In 1975 Zulu did indeed resign from the WCC and from the ANC and joined the resurrected Zulu cultural organisation, Inkatha, as its national chairman. ${ }^{49}$

In addition to alienating liberal opponents such as Bishop Zulu on principle, it was a reality that the WCC decision placed many liberal opponents of apartheid in an awkward and invidious position, giving the government ample ammunition to target them. Reflecting more widespread feeling, the Afrikaans theologian, Prof Ben Marais, a long-time critic of apartheid, wrote to Eugene Carson Blake, the general secretary of the WCC, an open letter in which he observed:

... by giving your support to a movement dedicated to revolution and violence and bloodshed if necessary, you have, as I see it, betrayed the Christian way in social and political reform and become in the terms of many "a subsidizer of violence". 50

For Marais, the WCC view of the ANC as essentially an organisation dedicated to fighting racism obscured its commitment to the violent overthrow of the South African state. Marais could thus not accept the WCC thinking that such support for the violence of the ANC could be equalised by appealing to the systematic violence of apartheid as they did. Blake did not respond to Marais, whose open letter quickly made the rounds in the European churches, because he was in the United States. But Albert van den Heuvel, the director of the WCC's Department of Communication, issued a preliminary response. While expressing his admiration for Marais, Van den Heuvel chided him on his failure to see the nuances in the situation and for his blanket description of the

46. Cited in R.S. Kumalo and H. Mbaya, "Against All Odds: Alphaeus Zulu and Racism in Church and Society", Studia Historiae Ecclesiasticae, 41, 2 (2015), p 12.

47. Historical Papers Collection, University of the Witwatersrand (hereafter WHP), Church of the Province of South Africa Papers (hereafter CPSA), AB 1291/A WCC Central Committee 1973, Letter to Rt. Revd. T.G.V. Inman, 1 March 1974.

48. WHP, CPSA, Letter to Rt. Revd. T.G.V. Inman, 1 March 1974.

49. B. Burnett, “Obituary: Alphaeus Hamilton Zulu (1905-1988)", Natalia, 18, 1988, pp 9396.

50. Pro Veritate, 9, 6 (October 1970), p 12. 
liberation movements as terrorists. Furthermore, Van den Heuvel assured Marais that the WCC grants to the ANC did not equate to a moral endorsement of violence, and instead appealed to Marais that such gestures could provide the ANC with the hope that with generous international allies, a violent overthrow of the apartheid regime could possibly be avoided through an alternative path to change. ${ }^{51}$

However, as churchmen within South Africa who were opposed to apartheid had feared, the WCC funding enabled the government to take the offensive against them. In parliament on 15 September 1970, Vorster signalled his intent to respond to the WCC decision. Should the churches choose not "to dissociate themselves" from the WCC, he observed,

I would be neglecting my duty ... if I did not take action against them, if I allowed more money to be collected in South Africa for transmission to that organization, if I allowed churches which . . . remain members to send representatives to conferences of that body. 52

As a signal of his intent, he deported two Anglican Stellenbosch-based priests, Robert Mercer and Bernard Chamberlain, after Mercer circulated a short response article in his church responding to the WCC decision. The article itself was relatively innocuous and even mildly critical of the WCC's Special Fund. It was exactly the mildness of Mercer's response, though, that caused Vorster offence and led to Mercer and Chamberlain being deported from South Africa. The prime minister also used the Special Fund as an opportunity to prevent money flowing in and out of the country between the WCC and the South African churches. ${ }^{53}$ This was a harsh blow. An example of the importance of such funding was provided by the Study Project on Christianity in an Apartheid Society (Sprocas 1), jointly commissioned by the SACC and the Christian Institute in 1969 to explore practical alternatives to apartheid, which had relied on overseas donors for a full 53 per cent of its capital. ${ }^{4}$ The churches would now be without recourse to such funding.

The South African churches, under the increased influence of their predominantly black laity, resisted Vorster's demand that they immediately dissociate themselves from the WCC. The United Congregational Church of Southern Africa, the Methodist Church of South Africa and the Church of the Province of South Africa, all decided to remain affiliated to the WCC. The Special Fund in fact created a moment for collective soul-searching. The Congregationalists pledged themselves anew "to work,

51. "A Preliminary Reaction to Prof. Marais' Letter by Dr A. B. van den Heuvel, Director, Department of Communication, WCC", at www.aluka.org Accessed 16 June 2008.

52. Cited in M. Horrell, A Survey of Race Relations in South Africa: 1970 (South African Institute of Race Relations, Johannesburg, 1971), p 16.

53. Horrell, A Survey of Race Relations in South Africa: 1970, p 17.

54. WHP: A 835/Aa, "Spro-cas Revenue and Expenditure Account, 1/2/69 - 31/5/69". 
by all means consistent with the Gospel, for justice, freedom, and racial reconciliation in Southern Africa". The Methodist Church "acknowledged its own shortcomings in seeking a solution to the problem of racism, and pledged itself to seek true unity between the races in the Church and the nation". The Anglicans recognised "the frustration and despair, which have impelled sons of Southern Africa to take drastic action against their own countries", seeing it as a "judgment upon our failure to embody God's righteousness in relationships between man and man in our society". 55 The SACC appointed Bishop Zulu to head a delegation to receive the WCC to discuss the Special Fund in 1971. Vorster granted the WCC permission to enter the country, but on condition that members of its delegation remained at Jan Smuts Airport for their deliberations; they were forbidden from travelling around the country. Furthermore, Vorster stipulated that the only point for discussion on the agenda could be the grants, and that lastly, that the WCC delegation should be reduced in size. Eugene Blake felt these conditions to be unacceptable and the WCC visit did not take place. ${ }^{56}$

Church historian and theologian, John de Gruchy, who was an active participant in the SACC at the time, reflected later on the impact and meaning of the grants on the churches in South Africa. The grants, he observed, constituted a profound test of the "fellowship and commitment of the churches". Recounting one story, De Gruchy told of a synod where a white pastor spoke against the grants on the grounds that at the time his son was serving with the army on "the border", to which a black pastor countered that his nephew was part of a liberation army fighting from the other side of the border. Furthermore, according to De Gruchy, the grants clarified the position of the churches in relation to apartheid for black Christians, where in many cases their participation in the English-speaking Church synods prevented the withdrawal of these churches from the WCC and served as a wakeup call for the churches that "time was running out" for peaceful means of political change, the only alternative would be violence. ${ }^{57}$ The severe test of the commitment of the English-speaking churches by the WCC's Special Fund, according to De Gruchy, acted as a refining process that resulted in "a new note of determination" in the churches to push the government to recognise the need for political equality for blacks and to forever jettison the ideal of separate development that stripped blacks of their citizenship rights. ${ }^{58}$

The view of the WCC grants taken by young black South Africans was further revealing. Bobby Marie grew up being involved with the Presbyterian Indian Mission in Meerbank, an Indian neighbourhood in Durban, and later became a well-known trade unionist with the Metal and Allied Workers Union (MAWU) and later the National Union of Metal Workers of South Africa (NUMSA). Marie particularly recalled the significance of the WCC's decision to support the ANC through its Special Fund as part

55. Cited in Horrell, A Survey of Race Relations in South Africa: 1970, p 18.

56. B. Sjollema, "Eloquent Action", in Webb (ed.), A Long Struggle, p 16.

57. De Gruchy, The Church Struggle in South Africa, pp 136-137.

58. De Gruchy, The Church Struggle in South Africa, p 138. 
of the organisation's wider perceived role at the time. As Marie recalled, from the way the WCC was perceived on the ground, its small sum of money to the ANC was viewed as support for its aims and chosen method of a violent overthrow of the state in South Africa. ${ }^{99}$ This confirms Welch's emphasis on the WCC's use of symbolic politics. In this sense, the intended message of the WCC was heard, that the world body had chosen to side with those fighting against apartheid, even if this was done with violence.

The decision of the WCC Central Committee to release funds to the PCR, in the knowledge that some of the funds would be channelled to organisations involved in armed struggles against the white minority states, thus impacted powerfully on South Africa. Part of the reason for the emotional impact of the decision was the ideological justification of apartheid, which presented itself as defending Christian civilisation against the forces of atheistic Communism. The open support by the WCC of such forces smacked of open betrayal. However, the WCC grants served to bring into clear relief the oppressive structure of apartheid, chiefly through creating violent indignation by many white Christians - in contrast to silent support from black Christians.

This section has demonstrated how the grants from the WCC served to emphasise the polarised nature of South Africa, which could be crudely summed up as white condemnation of the grants and black support. However, not all black Church leaders were comfortable in supporting the WCC position, as the case of Bishop Alpheus Zulu shows. The next section explores some of the differences in the response to the grants in South Africa's northerly neighbour, Botswana, a country where Christianity was also strongly present; it received the WCC grants with quiet support of a more uniform nature.

\section{The impact of the Special Fund on Botswana}

Mirroring the response of South Africa's black majority, Botswana responded to the grants with quiet support. This was in part because the grants provided a source of assistance for the country's support of political refugees from the liberation struggles in neighbouring countries. Furthermore, the Botswana Christian Council (BCC) was preoccupied with the pressing and immediate needs it faced at the time. Lastly, the spectre of racial war was absent from the country. It had recently been granted independence so the BCC did not even consider it necessary to comment publically on the WCC grants; instead it quietly accepted this assistance. Together these factors indicate that the emotional import of the WCC decision was due to the high levels of public fear in South Africa in addition to the theological dimensions of the controversy. The following section begins by outlining the history of Botswana's stance vis-à-vis the liberation struggles in Rhodesia and South Africa, and secondly looks at the founding of the BCC to help explain the nature of the impacts of the WCC grants in the country.

59. Bobby Marie, interview conducted by author, Johannesburg, 15 February 2013. 
Botswana served, as Tlou observes, as "an important centre for anti- apartheid activity related to South Africa" and was furthermore "a critical transit point for activists fleeing Mozambique, Angola, Zimbabwe, Namibia, South Africa. In this sense it became, for some, a place of refuge". ${ }^{60}$ In addition to being a place of refuge, Botswana constituted a challenge to the prejudices and fears that characterised Rhodesia and South Africa at the time. As a contemporary observer put it, Botswana under President Seretse Khama, provided "for South Africa and Rhodesia, a window to an alternative society - open, prosperous and non-racial". "This", the writer concluded, "must surely help to lower the level of fear which is perhaps the greatest obstacle to change in these countries". ${ }^{61}$ The presentation of an "alternative", open society was a conscious strategy that Khama also worked to promote. As the Johannesburg paper The Star noted, Khama "has said that his country is trying to influence white attitudes in South Africa by demonstrating that non-racialism does work, and that a black state can develop to stand on its own feet". ${ }^{62}$ In this way, Botswana stood as a telling corrective to the kneejerk and common sense arguments that were put forward for the continuance of white supremacy in South Africa and Rhodesia. Botswana's moderate government and its stability were part of its ideological response to the cynicism and fear that informed apartheid thinking.

In addition to presenting an alternative society, Botswana had economic and political interests in trying to bring about change in its neighbours. At independence in 1966, the country was held almost completely hostage to South Africa and Rhodesia, and narrowly escaped being incorporated into the former. Upon becoming independent, as a WCC observer later put it, the "meagre educational infrastructure that did exist ... was a result of missionary activity plus community based self-help projects". 63 At a conference held in 1976 by the WCC and the AACC, delegates noted that "it is certain that the content and extent of development in Botswana will remain limited without the overthrow of the white racist regimes and a radical transformation of the entire socio-economic structures of those societies." 64 Thus Botswana had a deep inherent interest in the change of the racial policies of its neighbours. In addition, Khama pointedly refused South African aid. As his contemporary, President Julius

60. T. Tlou, "Botswana: The Road to Independence", online at http://www.aluka.org Accessed 3 April 2013.

61. D. Anderson, "President Sir Seretse Khama: A Personal View", in G. Carter and E. Morgan (eds), From the Frontline: Speeches of Sir Seretse Khama (Hoover Institution Press, California, 1980), p xix.

62. Cited in M. Horrell, A Survey of Race Relations in South Africa: 1971 (South African Institute of Race Relations, Johannesburg, 1972), p 100.

63. WCC, "Problems and Prospects of Development in Botswana", AACC/PCR-WCC Consultation: The Liberation of Southern Africa, Mindolo, Kitwe, Zambia, 25 to 30 November 1976, p 8, online at www.aluka.org Accessed 16 April 2013.

64. WCC, "Problems and Prospects of Development in Botswana", pp 10-11. 
Nyrere of Tanzania mentioned, Khama would not "accept any loans, grants, or technical assistance, from the South African government" on account of South Africa's racist policies, despite the fact that Botswana sorely needed foreign financial aid and investment. 65

However, Khama was forced to work a "tightrope" as a so-called front line state. Fearing to incur direct retaliation from either Rhodesia or South Africa, Khama was forced to refuse bases to "the Freedom Fighters of Zimbabwe, Namibia, or South Africa" but had "made it quite clear" that the country would "accept refugees from political and racial persecution, and either give them somewhere to stay and land to live by or help them to move on to other better placed countries." 66 The Botswana government also sought to obviate its dependence on Rhodesia and South Africa by seeking other diplomatic links, especially with Eastern European countries and China. It openly stood against white rule in the United Nations and the Organisation of African Unity and "pledged support to the African people's struggle against racist minority rule in Zimbabwe and apartheid". 67

But the influx of refugees created tensions within Botswana society. As a contemporary observer saw, the impact of "thousands of refugees, many urbanized and politically active" was amplified because of "the small and relatively unsophisticated" nature of Botswana society which had "created problems for President Khama, and some tensions in the country". ${ }^{68}$ The influx of refugees was a problem that Botswana faced from before its independence. In fact it was a two-fold problem: "how to choke off the 'down' pipeline sending 'trained saboteurs' to South Africa, and that of refugees who had settled down to stay - some of them despite attempts to encourage them to leave".69 This reticence regarding refugees did change in the following years, something that Parsons attributes to a particularly prominent refugee, the leading black South African academic Z.K. Matthews, who took up a position with the WCC and was then later recruited as an ambassador of Botswana to the United Nations before his death in $1968 .{ }^{70}$ As Khama described it to the United Nations in New York, "Botswana grants asylum and assistance to genuine political refugees who seek our aid". ${ }^{71}$ In reality, as Parsons notes, "refugee work increasingly devolved onto the

65. J. Nyrere, "Foreword", in Carter and Morgan (eds), From the Frontline, p xi.

66. Nyrere, "Foreword", p xiii.

67. WCC, "Problems and Prospects of Development in Botswana", p 8.

68. Anderson, "Khama: A Personal View", p xviii.

69. N. Parsons, “The Pipeline: Botswana's Reception of Refugees, 1956-68”, Social Dynamics, 34, 1 (2008), p 24.

70. Parsons, "The Pipeline", p 28.

71. S. Khama, "Address to the General Assembly of the United Nations, New York, 24 September 1969", in Carter and Morgan (eds), From the Frontline, p 65. 
Botswana Council of Churches and the International Refugee Council of Zambia, with Z.K. Matthews helping to coordinate from Geneva". ${ }^{72}$

The Botswana Christian Council (BCC) was a relatively new organisation. Talks between the leading Christian denominations about the creation of an ecumenical organisation had begun in September 1964, comparatively much later than South Africa, where the Christian Council of South Africa had been formed in 1936. After almost two years of negotiations, the BCC was founded on 21 May 1966 in Gaborone. Launched with very practical relief programmes in mind, the BCC was "formed by churches that were already involved in community development work and pioneered among others, health and education services, provision of clean water and drought relief programmes". ${ }^{73}$ The founding members were the Anglican Church, the London Missionary Society, the Methodist Church and the United Free Church of Scotland, ${ }^{74}$ but the BCC later came to affiliate most of Botswana's Christian Churches. The Rev. Brian Bailey, a London Missionary Society missionary, who served as the BCC's first general secretary from 21 May 1966 until 1973, recalled the reason for the birth of the council, as principally a "response to poverty" rather than a desire for Christian unity. The response efforts were also inhibited by a duplication of administration through two councils of churches located in Francistown and Gaborone. Bailey remembers that:

... a national council was considered to be more effective in administering the relief programme ... [and] the resources, which were entering the country from ecumenical donor agencies from Europe and North America. Hence the Council evolved out of a social need, rather than general desire for unity. ${ }^{75}$

For Botswana, the WCC provided immediate funding and assistance. In the light of this assistance by the WCC and its own important role in the care of refugees, the BCC was silent over the WCC grants to the liberation movements. In his history of the Botswana Christian Council, James Amanze, professor of Theology and Religious Studies at the University of Gaborone, does not address the BCC stance in relation to the grants, although they were undoubtedly a watershed moment for the churches in the region. ${ }^{76}$ Perhaps it was because the Botswana Christian Council, as Amanze

72. Parsons, "The Pipeline", p 23.

73. Botswana Daily News, "Botswana: BCC Celebrates Golden Jubilee", online at http://allafrica.com/stories/201605230207.html Accessed 2 April 2017.

74. D. Mosweunyana and C.B. Montsho, "From Humble Beginning to Prosperity: Processes and Successes of Building Resilient Communities (Etsha Villages), Botswana Christian Council", in R.N. Lekoko (ed.), Cases on Grassroots Campaigns for Community Empowerment and Social Change (IGI Global, Hershey, 2015), p 105.

75. Cited in J. Amanze, Ecumenism in Botswana; The Story of the Botswana Christian Council (Pula Press, Gaborone, 2006), pp 74-75. There is also no explicit attention given to the issue in the Botswana Council of Churches' collections in Gaborone or in the Botswana National Archives. J. Amanze, personal communication, 8 May 2013.

76. Amanze, Ecumenism in Botswana. 
argues, grew out of the practical need for church intervention as a response to a serious drought crisis rather than from an ecumenical ideal. There was further lack of comment on the Special Fund in the official minutes of the Botswana Council of Churches. ${ }^{77}$ Instead, the focus was on moral issues such as the problem of alcoholism in Botswana and the death penalty, as well as on the pressing concern of refugees. However, Amanze indicated to me that his sense was that the Botswana Council of Churches "welcomed the decision by the WCC to support the liberation movements in Southern Africa because this was the only way they could fund their activities of looking after the refugees". But more broadly, Amanze pointed to the ethical element of a decision to support the anti-apartheid struggle when he observed "To them it was a moral duty to position themselves on the same side like the WCC". ${ }^{78}$

Emphasising the difference between the symbolism of the grants and their effects, in an interview Howard Trumbull reflected on the challenge that administering the funds created. ${ }^{79}$ A Congregationalist missionary with the American Board Mission, he had been deported along with his family from South Africa in 1971 for his work supporting banned persons. As treasurer for the Congregationalist Church in Durban, he had rented the church offices in Beatrice Street to Steve Biko and Barney Pityana who had set up the South African Students' Organisation (SASO) headquarters there. ${ }^{80}$ He had also known Chief Albert Luthuli before his untimely death. Trumbull was named as a "co-conspirator" with the Anglican Dean of Johannesburg, Revd Gonville ffrench-Beytagh, who was arrested on the charge of high treason by the South African government and charged "under the Suppression of Communism Act, with having participated in the activities of organizations declared unlawful and carrying on these activities". ${ }^{81}$ Hired in November 1971 and initially based at Francistown, Trumbull took over the administration of the funds for refugees on behalf of the Botswana Christian Council. As a welfare officer he was also responsible for the running of the socalled White House, the centre in Francistown, managed by the Christian Council, for single refugees who were in transit.

It was a stormy relationship with the refugees, because one of Trumbull's first moves was to cut the amounts the refugees were receiving, which he maintained to me was as a result of a cut in funding from the United Nations high commissioner for refugees and the frivolous policy of his predecessor. Unsurprisingly this led to seething discontent. As a letter from the Francistown refugees addressed to the government expressed it: “... a crisis is now fast developing ... and for the sake of good relations all around we request that Mr Howard Trumbull and Mr F. Taylor be removed from all

77. WHP, AC 263/21.3 B30/1, Minutes of the Botswana Christian Council.

78. James Amanze, personal communication with author, 8 May 2013.

79. Howard and Dave Trumbull, Skype interview with the author, 22 May 2013.

80. I. Macqueen, "Re-imagining South Africa: Black Consciousness, Radical Christianity and the New Left, 1967-1977”, DPhil, University of Sussex, 2011, p 158.

81. Horrell, Survey of Race Relations in South Africa: 1971, pp. 87-88. 
contact with refugees forthwith". As part of their grievances, they listed Trumbull's "unsympathetic" and "threatening" attitude, his perceived withholding of funds, and his insistence on photographing recipients of funds. ${ }^{82}$ In their letter, the Francistown refugees argued that funds from the World Council of Churches had been made available for them, but that since "December 1970, the Botswana Christian Council has embarked on a systematic campaign to reduce subsistence allowances paid to refugees as if they were intent to have them out of the country". ${ }^{83}$ Matters reached a head, when refugees staged a protest outside Trumbull's house on 7 January 1972, holding placards with slogans like: "Trumbull is my shepherd and I shall not eat"; "Trumbull is a monster"; "Trumbull shall not eat if we don't eat - to hell with baaskap in refugee relief"; "Hunger knows no bounds - please baas give us bread"; and "We want our children educated - Howard Trumbull misled the dean". Trumbull contacted the area superintendent who sent an armed guard to watch the house. A police document listed Godfrey Beck, Dile Kote, Elliot Moyo, Herbert Maposa, Albino Pereira Francesco Chicole, Solly Ndlovu and Jeremiah Mbuli as the ringleaders of the demonstration. Altogether the police reported 31 refugees present at the Francistown demonstration. 84

In response to the mounting criticism of the BCC and Trumbull, the BCC general secretary, Brian Bailey, wrote an open letter to a local newspaper in August 1972 to refute some of the allegations against the organisation and Trumbull made by the refugees. He noted that Botswana had a total population of 4000 refugees, most of whom were well integrated in the north-western part of the country. It was only the minority who were in Francistown. He rejected the claims against Trumbull as "unfair and untrue", most of which proved "far from genuine". The BCC endeavoured to "act as a steward of funds donated by individuals and organisations overseas for the alleviation of suffering amongst refugees" and that as "good stewards ... it is our responsibility to sincerely assess the genuineness of any application". ${ }^{85}$ Such was the tenor of the discussions that the Botswana Christian Council was involved with, and it seems that the funds from the World Council of Churches were received gratefully and welcomed. The focus of grievances was limited to a small number of refugees whose claims for financial help, in the view of the council, were dubious.

82. Letter from Francistown refugees to president's office, 7 January 1972. My thanks to Dave Trumbull for sharing this private document as well as further private documents of Howard Trumbull noted below.

83. Letter from Francistown refugees, to president's office, 7 January 1972.

84. Privately held document, Howard Trumbull, Appendix B to Sf. 15/4(V) (44), 7 January 1972. List of refugees present at the demonstration with placards, Francistown, 7 January 1972.

85. Private document, Howard Trumbull. Letter from Brian Bailey to the Mmegi Wa Dikgang, editor, Serowe, 26 August 1972. 
In an interview conducted with Bernard Spong, originally a London Missionary Society (LMS) missionary to the northern Cape, who stepped into a leadership role with the United Congregational Church of Southern Africa (UCCSA) and later served as a communications officer for the SACC, ${ }^{86}$ he expressed no surprise that the BCC did not comment on the WCC grants. Spong had known Brian Bailey personally, because they had attended seminary together in Lancashire, England, before leaving for Africa. Elaborating on his sentiment, he emphasised Botswana's "mild form of politics" and its paternalist government structure, intimately linked to the LMS, which had seen another LMS missionary, Alfred Merriweather, accepting the independence of Botswana in 1966 and serving as the first speaker of Parliament. Spong emphasised to me that Botswana's attitude towards South Africa's politics was of concern "only as far as it affected them". ${ }^{87}$

Spong's comments support the picture of the BCC that has emerged from previous evidence, that in a sense the grants by the World Council of Churches passed them by as a theological or political issue. They were deeply involved in the support of refugees in Botswana and therefore stood to gain from the grants, but the deeper moral question was elided by the pragmatic concerns of running a poverty relief and ecumenical organisation. He also explained to me that some of the visceral responses the WCC grants evoked from whites in South Africa tapped into deep-seated fears, which were in turn manipulated by the apartheid government. This insight sheds further light on the lack of a similar emotional response to the WCC grants in Botswana, which was already an independent African country, although still very much waiting to grow out of its paternalist structures. Without the paralysing ideology of apartheid and with a moderate government that did not produce the propaganda and indoctrination that the South African government engaged in, the visceral response to the WCC's symbolic solidarity with the liberation movement was absent.

\section{Conclusion}

While acknowledging the need for the WCC to make a symbolic gesture of support in the context of worldwide racism, this article has shown the mixed impacts of the grants in both South Africa and Botswana. In South Africa it had the effect of challenging churches to take a clearer stand against apartheid but it also provided the apartheid state with reason to intensify repression against Christians opposed to the regime. Furthermore, the grants had the effect of alienating liberal opponents of apartheid, such as Professor Ben Marais and Bishop Zulu. In Botswana, the grants did not create the political and emotional divisions seen in South Africa, but they also created their own set of problems surrounding the administration of the funds.

86. For his autobiography, see B. Spong, Sticking Around (Cluster Publications, Pietermaritzburg, 2006).

87. Bernard Spong, interview with author, Johannesburg, 19 June 2013. 
This article has confirmed Welch and Mufamadi's assessment of the significance of the WCC grants, in Welch's description, as a form symbolic politics. In effect, the WCC decision acted as a catalyst to pronounce deeper theological and ethical persuasions but simultaneously placed considerable strain on the ecumenical project in South Africa. The payment of the grants in effect constituted an extreme litmus test of where the loyalties of the churches lay, whether with the status quo, or with the oppressed. The absence of stifling fear of black political control in Botswana meant that the response to the WCC grants was not freighted with the same emotional force as in South Africa.

The WCC grants constituted a significant move towards a coalescing global condemnation of apartheid in which the ecumenical movement took the lead. Even though the sums of money it allocated were relatively small, the WCC was able to use the special grants as a symbolic act of solidarity with the oppressed majority. Given the importance of Christianity in southern Africa, and the theological rationale that underpinned the apartheid state itself, the WCC grants to the liberation movements were one of the clearest symbolic acts in a growing international movement to ostracise and eliminate the racist system. The decision by the WCC created inevitable problems, debates and multiple repercussions; it was a crucial form of international pressure that shook Christians and leaders alike in South Africa and Rhodesia, contributing to the decline of minority rule.

\section{REFERENCES}

Adler, E., A Small Beginning: An Assessment of the First Five Years of the Programme to Combat Racism (World Council of Churches, Geneva, 1974).

Amanze, J., Ecumenism in Botswana: The Story of the Botswana Christian Council (Pula Press, Gaborone, 2006).

Anderson, D., "President Sir Seretse Khama: A Personal View", in Carter, G. and Morgan, E. (eds), From the Frontline: Speeches of Sir Seretse Khama (Hoover Institution Press, Stanford, 1980).

Botswana Daily News, "Botswana: BCC Celebrates Golden Jubilee", online at http://allafrica.com/stories/201605230207.html

Burnett, B., “Obituary: Alphaeus Hamilton Zulu (1905-1988)”, Natalia, 18 (1988).

Carter, G. and Morgan, E. (eds), From the Frontline: Speeches of Sir Seretse Khama (Hoover Institution Press, Stanford, 1980).

Chikomo, H., "The Struggle of the Church with a Racial Government Policy: Rhodesia", WCC Consultation on Racism, London, 19 to 24 May 1969, online at http://www.aluka.org/action/showMetadata?doi=10.5555/AL.SFF.DOCUMENT .ydlwcc0149

Couper, S., "Emasculating Agency: An Unambiguous Assessment of Albert Luthuli's Stance on Violence", South African Historical Journal, 64, 3 (2012). 
De Gruchy, J., The Church Struggle in South Africa, 2nd ed. (Eerdmans and David Philip, Grand Rapids and Cape Town, 1986).

De Villiers, W.B., "Editorial”, Pro Veritate, 9, 6 (October 1970).

Dubow, S., Scientific Racism in Modern South Africa (Cambridge University Press, Cambridge, 1995).

Duncan, G. and Egan, A., "The Ecumenical Struggle in South Africa: The Role of Ecumenical Movements and Organisations in Liberation Movements to 1965", Ecclesiastical Law Journal, 17, 3 (2015).

Emerson Vermaat, J.A., The World Council of Churches and Politics, 1975-1986 (Freedom House, New York, 1989).

Gurney, C., "The 1970s: The Anti-Apartheid Movement's Difficult Decade", Journal of Southern African Studies, 35, 2 (2009).

Horrell, M., A Survey of Race Relations in South Africa: 1970 (South African Institute of Race Relations, Johannesburg, 1971).

Horrell, M., A Survey of Race Relations in South Africa: 1971 (South African Institute of Race Relations, Johannesburg, 1972).

Hudson, D., The World Council of Churches in International Affairs (The Faith Press, London, 1977).

Karis, T.G. and Gerhart, G.M. (eds), From Protest to Challenge: A Documentary History of African Politics in South Africa, 1882-1990, Volume 5, Nadir and Resurgence, 1964-1979 (Unisa Press, Pretoria, 1997).

Kumalo, R.S. and Mbaya, H., "Against All Odds: Alphaeus Zulu and Racism in Church and Society", Studia Historiae Ecclesiasticae, 41, 2 (2015).

Grobler, J.A., Decisive Clash: A Short History of Black Protest Politics in South Africa, 1875-1976 (Acacia, Pretoria, 1988).

Macqueen, I., "Re-imagining South Africa: Black Consciousness, Radical Christianity and the New Left, 1967-1977", DPhil, University of Sussex, 2011.

Macqueen, I., "Students, Apartheid and the Ecumenical Movement in South Africa, 1960-1975." Journal of Southern African Studies, 39, 2 (2013).

Marie, B., Interview conducted by author, Mayfair, Johannesburg, 15 February 2013.

Mayson, C., "The Story of the Christian Institute", in South African Democracy Education Trust, The Road to Democracy in South Africa, Volume 4, Part 2, 19801990 (Unisa Press, Pretoria, 2010).

Mosweunyana, D. and Montsho, C.B., "From Humble Beginnings to Prosperity: Processes and Successes of Building Resilient Communities (Etsha Villages), Botswana Christian Council", in Lekoko, R.N. (ed.), Cases on Grassroots Campaigns for Community Empowerment and Social Change (IGI Global, Hershey, 2015).

Mufamadi, T., "The World Council of Churches and its Programme to Combat Racism: The Evolution and Development of their Fight against Apartheid, 1969-1994", PhD thesis, University of South Africa, 2011.

Ndlovu, S.M., "The ANC in Exile”, in South African Democracy Education Trust, The Road to Democracy in South Africa, Volume 1 (1960-1970) (Zebra Press, Cape Town, 2004). 
Oldham, J., Christianity and the Race Problem (George H. Doran, New York, 1924).

Parsons, N., “The Pipeline: Botswana's Reception of Refugees, 1956-68", Social Dynamics, 34, 1 (2008).

Pretorius, H. and L. Jafta, L., “'A Branch Springs Out': African Initiated Churches”, in Elphick, R. and Davenport, T.R.H (eds), Christianity in South Africa: A Political, Social and Cultural History (University of California Press, Berkley, Los Angeles, 1997).

Robertson, J. “Obituary: The Most Rev. Bill Burnett”, The Independent, online at http://www.independent.co.uk/news/people/obituary-the-most-rev-billburnett-1447654.html

Ryan, C., Beyers Naudé: Pilgrimage of Faith (David Philip, Cape Town and Johannesburg, 1990).

Salamon, L., "The Rise of the Non-profit Sector", Foreign Affairs (1994).

Setiloane, G., "The Ecumenical Movement in Africa: From Mission Church to Moratorium", in Villa-Vicencio, C. and De Gruchy J.W. (eds), Resistance and Hope: South African Essays in Honour of Beyers Naude (Eerdmans, Grand Rapids, 1985).

Sjollema, B., "Eloquent Action", in Webb, P. (ed.), A Long Struggle: The Involvement of the World Council of Churches in South Africa (WCC Publications, Geneva, 1994).

Sjollema, B., Never Bow to Racism: A Personal Account of the Ecumenical Struggle (World Council of Churches, Geneva, 2015).

Skinner, R., "The Moral Foundations of British Anti-Apartheid Activism, 1946-1960", Journal of Southern African Studies, 35, 2 (2009).

Skinner, R., The Foundations of Anti-Apartheid: Liberal Humanitarians and Transnational Activists in Britain and the United States, c. 1919-64 (Palgrave Macmillan, Houndmills, 2010).

SASO Newsletter, September 1970.

South African Democracy Education Trust, The Road to Democracy: South Africans Telling their Stories, Volume 1 (Molautse Trust, Johannesburg, 2008).

South African History Online, "A Message to the People of South Africa: Authorised Summary, 1968", online at http://www.sahistory.org.za/archive/a-message-tothe-people-of-south-africa-authorised-summary,-1968.

Spong, B., Interview conducted by author, Johannesburg, 19 June 2013.

Strassberger, E., "Ecumenism in South Africa, 1936-1960 with Special Reference to the Mission of the Church", DTh thesis, Stellenbosch University, 1971.

Suttner, R., "'The Road to Freedom is via the Cross': 'Just Means' in Chief Albert Luthuli's Life", South African Historical Journal, 62, 4 (2010).

Thörn, H., Anti-Apartheid and the Emergence of a Global Civil Society (Palgrave Macmillan, Houndmills, 2006).

Thomas, D., Christ Divided: Liberalism, Ecumenism, and Race in South Africa (Unisa Press, Pretoria, 2002).

Tlou, T., "Botswana: The Road to Independence”, online at http://www.aluka.org Trumbull, H. and D. Skype, D, Interview conducted by author, 22 May 2013. 
Walshe, P., Church versus State in South Africa: The Case of the Christian Institute (C. Hurst \& Co., London, 1983).

Webb, P. (ed.), A Long Struggle: The Involvement of the World Council of Churches in South Africa (WCC Publications, Geneva, 1994).

Welch, C.E., "Mobilizing Morality: The World Council of Churches and its Program to Combat Racism, 1969-1994", Human Rights Quarterly, 23, 4 (2001).

Williams, E., The Politics of Race in Britain and South Africa: Black British Solidarity and the Anti-Apartheid Struggle (I.B. Tauris, London, 2012).

World Council of Churches, Minutes and Reports, 23rd Meeting, University of Kent, Canterbury, 12 to 22 August 1969 (WCC publications, Geneva, 1969).

World Council of Churches, Minutes and Reports of 24th Meeting, Addis Ababa, Ethiopia, 10 to 21 January 1971 (WCC publications, Geneva, 1971).

World Council of Churches, "Problems and Prospects of Development in Botswana", AACC/PCR-WCC Consultation: The Liberation of Southern Africa, Mindolo, Kitwe, Zambia, 25 to 30 November 1976, online at www.aluka.org

Zondi, S., "Of Faith and Action: Aspects of the Role of Faith Institutions in the Struggle against Apartheid", in South African Democracy Education Trust, The Road to Democracy in South Africa, Volume 4, Part 2, 1980-1990 (Unisa Press, Pretoria, 2010). 